\title{
ANALISIS KESALAHAN SISWA SMK DALAM MENYELESAIKAN SOAL MATEMATIKA BERDASARKAN ANALISIS KESALAHAN NEWMAN
}

\author{
Siti Imamatur Rohmah \\ Program Studi Matematika, STKIP PGRI Sidoarjo \\ sitiimamaturrohmah@gmail.com \\ Soffil Widadah \\ Program Studi Matematika, STKIP PGRI Sidoarjo \\ soffdah16@gmail.com \\ Eka Nurmala Sari Agustina \\ Program Studi Matematika, STKIP PGRI Sidoarjo \\ eka.agustina.15@gmail.com
}

\begin{abstract}
Abtrak:
Penelitian deskriptif kualitatif ini bertujuan untuk mendeskripsikan hasil analisis kesalahan siswa SMK dalam menyelesaikan soal matematika materi sistem persamaan linier tiga variabel. Penelitian ini dilakukan di SMK Persatuan 1 Tulangan pada tahun ajaran 2019/2020 di kelas X-Tata Busana. Subjek dipilih berdasarkan banyaknya kesalahan yang dilakukan dalam menyelesaikan soal. Adapun teknik pengumpulan data dalam penelitian ini menggunakan metode tes dan wawancara. Tes dilakukan kepada semua siswa di kelas X-Tata Busana. Dari hasil tes soal diambil subjek yang memiliki kesalahan terbanyak. Selanjutnya subjek yang terpilih diwawancara. Hasil tes dan wawancara dianalisis dengan menggunakan analisis kesalahan Newman yaitu kesalahan membaca, kesalahan memahami, kesalahan mentransformasi, kesalahan dalam keterampilan proses dan kesalahan pada jawaban akhir. Berdasarkan penelitian dengan menggunakan analisis Newman dapat disimpulkan bahwa siswa melakukan kesalahan membaca dengan bentuk kesalahan tidak dapat membaca katakata penting yang ada dalam soal, siswa melakukan kesalahan memahami dengan bentuk kesalahan tidak dapat menuliskan yang diketahui dan ditanyakan dan menuliskan tetapi salah, siswa melakukan kesalahan mentransformasi dengan bentuk kesalahan tidak dapat membuat model matematika, siswa melakukan kesalahan keterampilan proses dengan bentuk kesalahan tidak dapat menyelesaikan soal dan prosedur tidak sesuai, dan siswa melakukan kesalahan pada jawaban akhir dengan bentuk kesalahan menuliskan jawaban salah dan tidak menuliskan jawaban.

Kata Kunci: Analisis Kesalahan, Kesalahan Newman, Menyelesaikan soal, SPLTV
\end{abstract}

\begin{abstract}
:
This qualitative descriptive study aims to describe the results of the analysis of the errors of vocational students in solving mathematical problems of the three-variable linear equation system. This research was conducted in SMK Persatuan 1 in Tulangan in the year of 2019/2020 in X grade of clothing class. Subjects were chosen based on the number of mistakes made in solving the problems. As for the technique of collecting data in this research were used test and interview method. The test was done to all of the students of the $X$ grade of clothing class. From the outcome of the test was taken 3 subjects who has the most mistaken. Furthermore the chosen subject to be interviewed. The results of the test and interview were analyzed by using
\end{abstract}




\begin{abstract}
Newman error analysis that is reading error, understanding error, transform error, process skill error and final answer error. Based on the research by using Newman error analysis can be concluded that student did the reading error with the error form of unable to read the important words found in the question, students did the understanding error with the error form of unable to write what is known and what is asked and write it but wrong, student did the transform error with the error form of unable to make the mathematical model, students did the process skill with the error form of unable to to solve the problem and incompatible procedure, and student did the final answer error with error form of written error answer and did not write the answer.

Keywords: Error Analysis, Newman Error, Resolve the Problem, Liniear Equation of Three Variables System
\end{abstract}

\title{
PENDAHULUAN
}

Abstraknya objek kajian pada matematika, salah satunya berkaitan dengan konsep dalam menyelesaikan soal cerita. Permatasari, (2016:7) menyatakan soal cerita merupakan soal berbentuk cerita atau kalimat bermakna, dan terkandung konsep matematika yang dikaitkan dengan keadaan atau kehidupan sehari-hari yang dialami siswa. Diharapkan siswa mampu mengidentifikasi dan menganalisa masalah yang ada pada soal cerita. Siswa harus bisa membuat ide atau cara untuk menyelesaikan soal. Tetapi kenyataannya siswa masih banyak yang mengalami kesulitan. Widadah dan Afifah (2013) menyatakan bahwa belajar yang dilakukan secara terus menerus akan melancarkan proses belajar matematika.

Bentuk soal cerita pada materi Sistem Persamaan Linier Tiga variabel (SPLTV) dirasa rumit dan sulit untuk menemukan penyelesaiannya. Berdasarkan wawancara yang dilakukan peneliti dengan salah satu guru matematika di salah satu Sekolah Menegah Kejuruan (SMK) di Kecamatan Tulangan-Sidoarjo diperoleh informasi bahwa dalam materi SPLTV yang berbentuk soal cerita diperoleh pencapaian hasil belajar siswa masih rendah, dengan rincian kondisi sebagai berikut: 1) nilai rata-rata ulangan siswa sekitar 58 dengan Kriteria Ketuntasan Minimal (KKM) 75; 2) hanya sekitar $40 \%$ siswa dari setiap kelas yang tuntas belajar pada materi ini; 3) masalah translasi dan aplikasi dalam menyelesaikan materi ini menjadikan rendahnya hasil belajar siswa.

Menurut Agustina (2016), penyimpangan yang menyebabkan adanya perbedaan antara jawaban dengan proses penyelesaian soal matematika yang sebenarnya dapat dikatakan sebagai kesalahan menyelesaikan soal matematika. Sedangkan menurut Soedjadi (2000:1), kesalahan dapat terjadi karena adanya kesulitan. Hal ini menunjukkan bahwa salah satu indikator siswa dikatakan kesulitan belajar dapat dilihat dari adanya kesalahan yang dilakukan dalam menyelesaikan soal. Untuk menganalisis kealahan yang dilakukan siswa, dapat dilakukan dengan menggunakan metode analisis kesalahan Newman. Newman mengkategorikan kesalahan menjadi 5 (lima) tahapan analisis, yaitu: (1) Reading Error (kesalahan membaca), (2) Comprehension Error (kesalahan memahami), (3) 
Transform Error (kesalahan transformasi), (4) process skills error (kesalahan dalam keterampilan proses), dan (5) encoding Error (kesalahan pada jawaban akhir).

Prakitipong \& Nakamura (2006: 113) menyatakan bahwa, "The Newman Procedure is a method that analyzes errors in sentence problems“. Penjelasan tersebut menginformasikan bahwa prosedur Newman digunakan untuk menganalisis kesalahan pada masalah uraian. NEA (Newman's Error Analisys). "NEA was a powerful classroom diagnostic assessment and teaching tool for assessing, analysing and catering for student experiencing difficulties with mathematical word problems." NEA adalah penilaian diagnostik kelas yang kuat dan alat untuk menilai pengajaran, menganalisis dan mambantu kesulitan siswa menyelesaikan soal matematika yang berkaitan dengan masalah kata.

White (2010), kesalahan siswa ketika membaca biasanya karena kesulitan dalam memahami kosakata, bahasa, dan simbolisme matematika, ketidakmampuan siswa dalam memaknai setiap kata atau istilah maupun simbol-simbol dalam soal matematika. Kesalahan membaca dapat diketahui melalui proses wawancara. Pada kesalahan pemahaman, siswa mungkin dapat membaca masalah kata tetapi tidak dapat menggambarkan makna matematika dari suatu skenario. Hal ini berkaitan dengan ketidak mampuan siswa memahami secara lengkap terkait yang diketahui dan ditanyakan. Pada kesalahan mentransformasi, siswa dapat membaca dan memahami masalah kata tetapi tidak dapat mengidentifikasi algoritma yang diperlukan atau yang sesuai untuk menyelesaikannya. Algoritma adalah metode sistematis untuk memecahkan masalah tertentu, perhitungan berulang yang digunakan dalam mencari pembagi umum terbesar dari dua angka. Kesalahan dalam mentransformasikan terjadi karena ketidakmampuan siswa mengubah soal dalam bentuk matematika secara benar dan salah menggunakan simbol operasi hitung. Pada kesalahan ketrampilan proses, berkaitan dengan ketidaktahuan siswa tentang prosedur atau langkah-langkah yang seharusnya digunakan saat menyelesaikan soal. Kesalahan dalam keterampilan proses seorang siswa dapat membaca pertanyaan, memahami skenario dan mengidentifikasi algoritma yang diperlukan tetapi tidak dapat memproses algoritma untuk mencapai hasil yang benar.dikarenakan kurangnya terampil dalam proses perhitungan. Sedangkan Kesalahan notasi, siswa dapat menyelesaikan langkah demi langkah, seperti membaca, memahami dan memecahkan tetapi tidak dapat mengubah hasil matematika menjadi pernyataan yang dapat dimengerti umum sesuai yang ada dalam pentanyaan atau soal. Kesalahan dalam notasi biasanya kesalahan dalam proses penyelesaian.

Adapun tujuan menggunakan analisis kesalahan Newman adalah menganalisis kesalahan siswa menyelesaikan soal SPLTV. Dengan mengetahui apa saja kesalahan-kesalahan dan letak kesalahankesalahan siswa menyelesaikan soal SPLTV, diharapkan adanya pemilihan metode pembelajaran yang tepat dilakukan oleh guru dan tidak terulang kembali kesalahan yang sama di kemudian hari serta menjadikan siswa lebih teliti. 


\section{METODE}

Penelitian ini dilakukan untuk mendeskripsikan hasil analisis kesalahan yang dilakukan siswa dalam menyelesaikan soal SPLTV melalui metode Newman pada siswa SMK Persatuan -1 Tulangan kelas X-Tata Busana tahun ajaran 2019/2020. Pemilihan subjek dilakukan dengan menganalisis hasil tes, kemudian dipilih siswa dengan kesalahan terbanyak dan memperhatikan rekomendasi guru matematika. Kelas untuk penelitian ini adalah kelas X-Tata Busana yang terdiri dari 24 siswa. Instrumen penelitian terdiri dari 2 soal cerita tes SPLTV dan pedoman wawancara berbentuk semiterstruktur. Hasil tes dan wawancara kemudian dianalisis menggunakan metode kesalahan Newton. Berikut indikator analisis kesalahan.

Tabel. 1.1 Indikator Analisis Kesalahan

\begin{tabular}{|c|c|c|}
\hline No & $\begin{array}{l}\text { Analisis } \\
\text { Kesalahan } \\
\text { Newman }\end{array}$ & Indikator Analisis Kesalahan \\
\hline 1 & $\begin{array}{l}\text { Kesalahan } \\
\text { membaca }\end{array}$ & $\begin{array}{l}\text { - Siswa salah membaca kata-kata penting pada suatu pertanyaan } \\
\text { - Ketidakmampuan siswa membaca simbol atau kata kunci yang tertulis dalam } \\
\text { masalah. } \\
\text { - Siswa tidak memahami makna kata yang ada didalam soal. }\end{array}$ \\
\hline 2 & $\begin{array}{l}\text { Kesalahan } \\
\text { memahami }\end{array}$ & $\begin{array}{l}\text { - Siswa tidak menjelaskan yang diketahui dan yang tersirat atau tidak tertulis } \\
\text { dalam soal. } \\
\text { - Tidak menuliskan dan menjelaskan apa yang ditanyakan } \\
\text { - Melewatkan info penting dalam soal walau telah menuliskan apa yang diketahui } \\
\text { dan ditanyakan. } \\
\text { - Siswa tidak menangkap makna secara keseluruhan walau mampu membaca } \\
\text { semua kata, yang mengakibatkan siswa tidak dapat melanjutkan menyelesaikan } \\
\text { masalah. }\end{array}$ \\
\hline 3 & $\begin{array}{l}\text { Kesalahan } \\
\text { mentransformasi }\end{array}$ & $\begin{array}{l}\text { - Tidak dapat membentuk model matematika dari informasi yang didaptkan dalam } \\
\text { soal. } \\
\text { - Tidak tepat mengubah informasi pada soal menjadi model matematika. } \\
\text { - Tidak tepat menggunakan rumus atau teori. } \\
\text { - Tidak mampu mengidentifikasi operasi atau urutan operasi dalam } \\
\text { menyelesaikan masalah walau telah mampu memahami yang ditanyakan. }\end{array}$ \\
\hline 4 & $\begin{array}{l}\text { Kesalahan } \\
\text { keterampilan } \\
\text { proses }\end{array}$ & $\begin{array}{l}\text { - Kesalahan komputasi. } \\
\text { - Tidak dapat melanjutkan prosedur penyelesaian (macet). } \\
\text { - Siswa tidak mengetahui keakuratan prosedur yang digunakan walau telah } \\
\text { mengenali kesesuaian dan ketrurutan operasi yang digunakan. }\end{array}$ \\
\hline 5 & $\begin{array}{l}\text { Kesalahan pada } \\
\text { jawaban akhir }\end{array}$ & $\begin{array}{l}\text { - Tidak ada jawaban akhir } \\
\text { - Tidak tepat menuliskan jawaban akhir } \\
\text { - Tidak bisa menyatakan jawaban yang sesuai dengan konteks masalah walau } \\
\text { sebenarnya telah menemukan jawaban yang benar. }\end{array}$ \\
\hline
\end{tabular}

\section{HASIL DAN PEMBAHASAN}

Berdasarkan hasil penelitian, jumlah kesalahan yang dilakukan siswa SMK Persatuan 1 Tulangan yaitu kesalahan memabaca pada soal nomor 1 dan soal nomor 2 subjek tidak dianalisis secara keseluruhan karena hanya subjek terpilih yang dianalisis kesalahan membaca soal dengan wawancara. Jumlah kesalahan memahami sebanyak 40 kesalahan siswa. Jumlah kesalahan 
mentransformasi sebanyak 27 kesalahan siswa. Jumlah kesalahan dalam keterampilan proses sebanyak 19 kesalahan siswa. Jumlah kesalahan jawaban akhir sebanyak 23 kesalahan siswa.

Dengan demikian dapat disumpulkan kesalahan terbanyak terjadi pada kesalahan memahami, jumlah kesalahan terbanyak ke dua terjadi pada kesalahan mentransformasi, dan jumlah kesalahan terbanyak ke tiga pada kesalahan jawaban akhir. Jumlah kesalahan paling sedikit terjai pada kesalahan pada ketrampilan proses.

\section{Soal Tes}

"Jumlah tiga bilangan sama dengan 20. Tiga kali bilangan pertama ditambah bilangan kedua sama dengan 3 kali bilangan ketiga dikurangi dua. Jika bilangan pertama dan dua kali bilangan ketiga sama dengan tiga kali bilangan kedua. Maka nilai masing-masing ketiga bilangan adalah..."

Berikut cuplikan hasil pekerjaan dan wawancara dengan Subjek berkaitan dengan pengerjaan tes soal:

\section{Kesalahan Membaca}

Subjek dikatakan melakukan kesalahan membaca jika salah membaca kata-kata penting dan tidak memahami makna kata yang ada pada soal. Kesalahan membaca terlihat pada hasil wawancara berikut.

$\begin{array}{lll}\text { P-1 } & : \text { Sekarang coba kamu baca soal cerita tersebut! } \\ \text { SP-1 } & : \text { Jumlah tiga bilangan hasilnya 20. Selanjutnya Tiga kali } \\ & \text { bilangan pertama yang ditambah bilangan kedua sama saja } \\ & \text { dengan } 3 \text { kali bilangan ketiga dikurangi dua. Jika bilangan } \\ & \text { pertama dan dua kali bilangan ketiga sama dengan tiga kali } \\ & \text { bilangan kedua. Maka nilai masing-masing ketiga bilangan } \\ & \text { adalah... } \\ & : \text { Apa makna dari soal yang kamu baca? } \\ \text { P-2 } \quad \text { SP-2 } & \text { Bilangan pertama diketahui 20, bilangan kedua dan ketiga } \\ & \text { belum diketahui }\end{array}$

Hasil transkip wawancara menunjukkan bahwa Subjek penelitian tidak memahami kata-kata penting yang ada di dalam soal yaitu menjelaskan jumlah tiga bilangan sama dengan 20 sebagai $\mathrm{a}=$ 20. Dengan demikian berdasarkan hasil wawancara menunjukkan bahwa subjek penelitian melakukan kesalahan membaca karena tidak dapat memahami makna kata penting yang ada di dalam soal.

\section{Kesalahan Memahami}

Subjek dikatakan melakukan kesalahan dalam memahami jika tidak mampu menjelaskan yang diketahui dan yang tersirat dalam soal, tidak menuliskan dan menjelaskan maksud soal, dan menuliskan yang diketahui dan ditanyakan, tetapi melewatkan info penting, serta tidak menangkap 
makna secara keseluruhan walau mampu membaca semua kata dalam masalah, sehingga tidak dapat melanjutkan menyelesaikan masalah. Kesalahan memahami dapat diketahui dari tes soal dan wawancara. Berikut hasil tes Subjek penelitian:

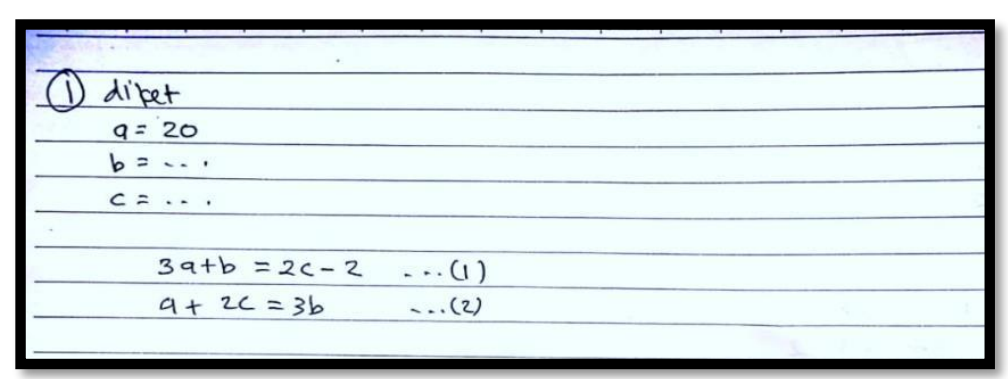

Gambar 1. Hasil Tes Soal, Kesalahan Memahami

Berdasarkan gambar 1 terlihat bahwa subjek penelitiantidak menjelaskan apa yang diketahui dan ditanyakan. Terlihat dapa lembar jawaban subjek penelitian tidak menuliskan yang diketahui, hanya menuliskan $\mathrm{a}=20$ tidak ada kelanjutannya. Hal tersebut sesuai dengan hasil wawancara peneliti dengan subjek penelitian berikut:

$\begin{array}{lll}\text { P-5 } & \text { : } & \text { Jelaskan apa saja pertanyaan yang ada dalam soal cerita tersebut? } \\ \text { SP-5 } & : \text { Diketahui } a=20, b \text { belum diketahui, dan } c \text { belum diketahui } \\ \text { P-6 } & : \text { Kenapa kamu menjelaskan a=20, b belum diketahui dan c belum } \\ & \text { diketahui? } \\ \text { SP-6 } & : \text { Itu kak bilangan pertama itu sama dengan } 20 \text { jadi a=20 } \\ \text { wawancara } & \text { tersebut menunjukkan bahwa Subjek penelitian menjelaskan apa yan }\end{array}$
diketahui adalah bilangan pertama menjadi a=20. Subjekmenjelaskan bilangan pertama dirubah menjadi a untuk dijadikan persamaan. subjek penelitianmampu menjelaskan apa yang diketahui tetapi tidak tepat. Dengan demikian, berdasarkan hasil tes dan wawancara diketahui bahwa subjek penelitian melakukan kesalahan memahami yaitu menuliskan dan menjelaskan yang diketahui dan ditanyakan tetapi tidak tepat karena tidak bisa membaca kata penting yang ada di dalam soal.

\section{Kesalahan Mentransformasi}

Subjek dikatakan melakukan kesalahan transformasi jika subjek tidak mengubah informasi dalam soal ke dalam bentuk model matematika, subjek mengubah informasi pada soal ke dalam bentuk matematika tetapi tidak tepat, dan subjek tidak tepat dalam menggunakan rumus atau teori yang digunakan. Kesalahan mentransformasi dapat diketahui dengan tes soal dan wawancara. Berikut hasil tes subjek penelitian. 


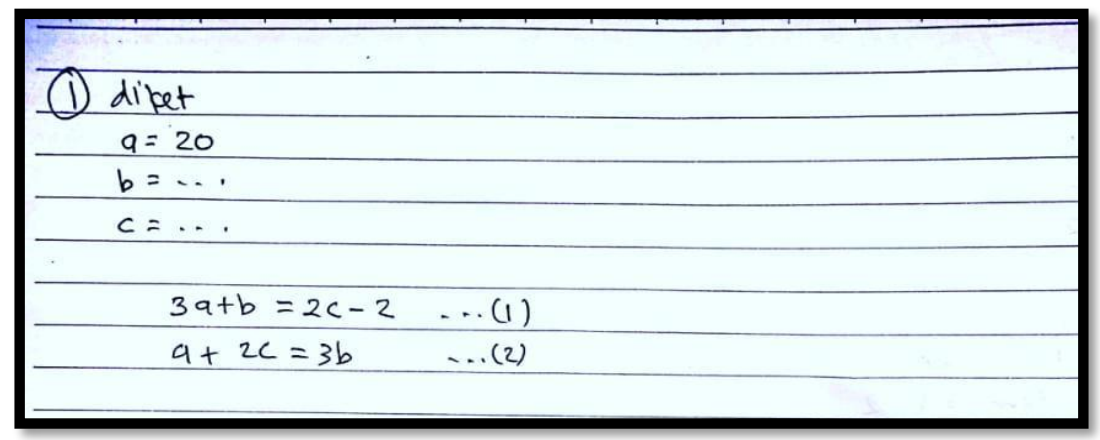

Gambar 2. Hasil Tes Soal, Kesalahan Mentransformasi

Berdasarkan gambar 2 terlihat bahwa subjek penelitian dapat mengubah informasi pada soal ke dalam bentuk matematika yaitu menuliskan hanya dua persamaan $3 a+b=2 c-2$ dan $3 a+b-$ $3 c=-2$. Persamaan yang dituliskan kurang satu persamaan yaitu $a+b+c=20$. Hal tersebut sesuai dengan hasil wawancara peneliti dengan Subjek penelitian berikut:

P-11 : Coba jelaskan bagaimana kamu membuat model matematika!

SP-11 : Tiga $a$ ditambah $b$ sama dengan $2 c$ dikurangi 2 persamaan 1 dan 3 a ditambah $\mathrm{b}$ dikurangi $3 \mathrm{c}$ sama dengan -2 sebagai persamaan 2. Jika ditulis seperti ini (menunjuk lembar jawaban $3 a+b=$ $2 c-2$ dan $3 a+b-3 c=-2)$

Hasil wawancara tersebut menunjukkan bahwa subjek penelitian menjelaskan cara menentukan model matematika dengan mentransformasikan Tiga a ditambah b sama dengan 2c dikurangi 2 persamaan 1 dan 3a ditambah b dikurangi 3c sama dengan -2 sebagai persamaan 2 . Subjek penelitian tidak bisa menjelaskan mengapa disetiap persamaan ada huruf abjad. Subjek penelitian juga menjelaskan hanya ada dua persamaan. Dengan demikian, berdasarkan hasil tes dan wawancara diketahui subjek penelitian melakukan kesalahan dalam mentransformasi yaitu mengubah informasi pada soal ke dalam bentuk matematika tetapi tidak tepat.

\section{Kesalahan dalam Keterampilan Proses}

Subjek dikatakan melakukan kesalahan dalam keterampilan proses jika melakukan kesalahan komputasi, tidak dapat melanjutkan prosedur penyelesaian (macet), dan tidak mengetahui keakuratan prosedur yang digunakan walau telah mengenali kesesuaian dan ketrurutan operasi yang digunakan. Kesalahan dalam keterampilan proses dapat diketahui dari tes soal dan wawancara. Berikut hasil tes Subjek penelitian: 


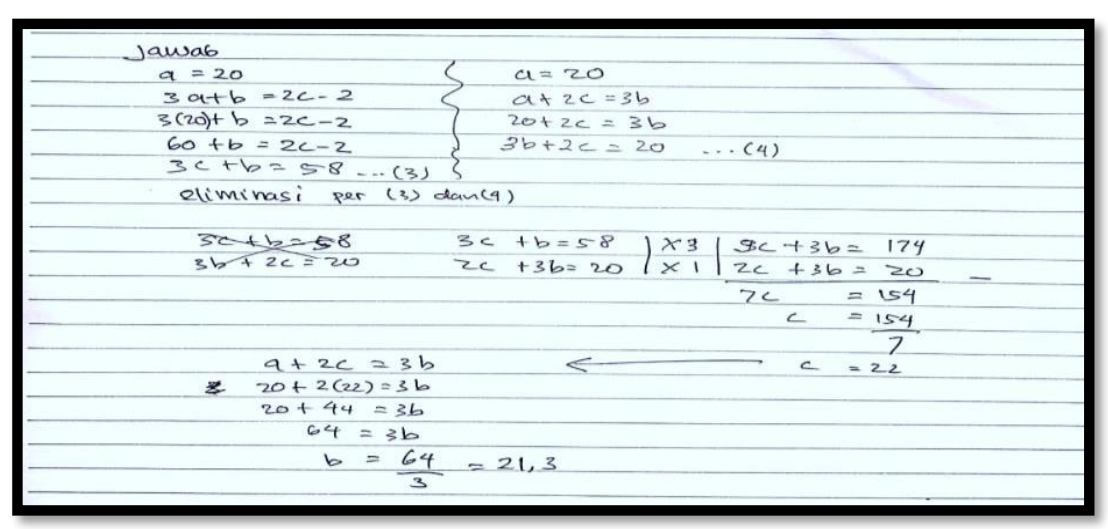

Gambar 3. Hasil Tes soal, Kesalahan dalam Keterampilan Proses

Berdasarkan hasil tes pada gambar 1.3 terlihat bahwa subjek penelitian memahami metode penyelesaian soal, tatapi karena subjek penelitian salah dalam memahami, sehingga dalam proses penyelesaian soal yang disubtitusikan salah yaitu bilangan pertama sama dengan $=20$. Hasil wawancara menunjukkan kesesuaian dengan analsis hasil tes tertulis siswa seperti berikut.

P-23 : Jelaskan bagaimana cara kamu menyelesaikan soal cerita SPLTV?

SP- : Pertama disubtitusikan $\mathrm{a}=20$ ke persamaan satu sehingga menjadi

$233 \mathrm{c}+\mathrm{b}=8$ menjadi persamaan 3 dan persamaan kedua menjadi $3 c+2 b=20$ menjadi persamaan 4 . Setelah itu dieliminasi persamaan 3 dan 4 hasilnya $\mathrm{c}=22$ terusdisubtitusi ke persamaan 2 .

Hasil wawancara tersebut menunjukkan bahwa subjek penelitian menjelaskan cara menyelesaikan soal SPLTV adalah yang pertama mensubtitusikan a $=20$ ke persamaan 1 sehingga menjadi $3 c+b=8$ sebagai persamaan 3 dan persamaan kedua menjadi $3 c+2 b=20$ sebagai menjadi persamaan 4 . kemudian mengeliminasi $\mathrm{b}$ pada persamaan 3 dan persamaan 4 hasilnya $\mathrm{c}=$ 22 . nilai $\mathrm{c}$ disubtitusikan ke persamaan 2 sehingga $\mathrm{a}=21,3$. Subjek penelitian menjelaskan prosedur pnyelesaian soal tetapi salah. Dengan demikian, berdasarkan hasil tes dan wawancara subjek penelitian ketahui subjek penelitian melakukan kesalahan dalam keterampilan proses. Subjek penelitian mengenali operasi yang sesuai atau urutan operasi untuk menyelesaikan soal tetapi tidak mengetahui prosedur yang diperlukan untuk menyelesaikan operasi tersebut secara akurat.

\section{Kesalahan pada Jawaban Akhir}

Kesalahan pada jawaban akhir dapat diketahui jika subjek tidak menuliskan jawaban akhir, subjek menuliskan jawaban akhir yang tidak tepat, dan subjek sebenarnya telah menyelesaikan soal dengan benar, tetapi tidak bisa menyatakan jawaban akhir yang sesuai dengan konteks masalah. Kesalahan pada jawaban akhir dapat diketahui dari tes soal dan wawancara. Berikut hasil tes Subjek penelitian: 


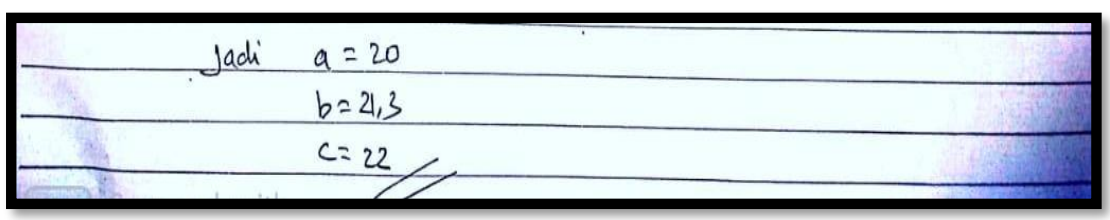

Gambar 4. Hasil Tes soal, kesalahan pada jawaban akhir

Berdasarkan hasil tes pada gambar 1.4 terlihat bahwa subjek penelitian menuliskan jawaban akhir tetapi tidak tepat yaitu" yaitu $a=20, b=21,3$ dan $c=22$. seharusnya "nilai masing-masing ketiga bilangan" yaitu $\mathrm{a}=5, \mathrm{~b}=6$ dan $\mathrm{c}=8$. Hal tersebut sesuai dengan hasil wawancara peneliti dengan SP3 berikut:

P-28 : Sekarang coba jelaskan jawaban akhir dari jawabanmu itu?

SP-28 : Jadi nilai dari bilangan tersebut adalah $\mathrm{a}=$ 20 karena sudah ada disoal, $\mathrm{b}=21,3$ dan $\mathrm{c}=22$

Berdasarkan hasil wawancara subjek penelitian menjelaskan cara menyeleaikan jawaban akhir tetapi salah yaitu $\mathrm{a}=20$ karena sudah diketahui didalam soal, $\mathrm{b}=21,3$ dan $\mathrm{c}=22$. Dengan demikian, berdasarkan hasil tes dan wawancara subjek penelitian diketahui melakukan kesalahan dalam jawaban akhir karena menuliskan jawaban akhir tetapi jawaban tidak tepat.

\section{SIMPULAN}

Jumlah Kesalahan tertinggi yang paling banyak dilakukan siswa adalah kesalahan memahami. Berdasarkan hasil tes jumlah kesalahan yang dilakukan sebanyak 40 kesalahan. Kesalahan tertinggi selanjutnya yang banyak dilakukan siswa adalah kesalahan mentransformasi. Jumlah kesalahan yang dilakukan siswa adalah sebanyak 27 kesalahan. Kesalahan tertinggi selanjutnya yang dilakukan siswa adalah kesalahan pada jawaban akhir. Jumlah kesalahan yang dilakukan siswa sebanyak 23 kesalahan. Sedangkan kesalahan paling rendah yang dilakukan siswa SMK adalah kesalahan pada keterampilan proses. Jumlah kesalahan yang dilakukan siswa sebanyak 19 kesalahan. Saran bagi guru, sebaiknya memfasilitasi kegiatan pembelajaran dengan latihan-latihan soal cerita pada materi sistem persamaan linier tiga variabel agar siswa tidak melakukan kesalahan dalam menyelesaikan soal cerita. Sedangkan bagi peneliti lain yang melakukan penelitian yang serupa dengan penelitian diharapkan untuk lebih mengembangkan dan memperluas materi, agar lebih banyak mendeteksi kesalahan-kesalahan siswa dalam menyelesaikan soal.

\section{REFERENSI}

Agustina, Eka Nurmala Sari (2016). Konsep Aljabar yang terlupakan. Jurnal Pendidikan Matematika STKIP PGRI Sidoarjo, Volume 2 No.1, April 2016.

Permatasari, E, G. 2016. Efektivitas Metode Penemuan Terbimbing untuk Meningkatkan Kemampuan Mengasosiasikan Soal Cerita "Peluang” pada Mata Pelajaran Matematika Siswa Tunanetra 
Kelas XI IPS SMALB PTN Lawang. Skripsi tidak dipublikasikan, Malang, Universitas Negeri Malang.

Prakitipong, N. \& Nakamura, S. (2006). Analysis of Mathematics Performance of Grade Five Students in Thailand Using Newman Procedure. Journal of International Cooperation in Education, Vol.9, No.1, (2006) pp.111-122.

Soedjadi, R. 2000. Kiat Pendidikan Matematika Di Indonesia. Surabaya: Departemen Pendidikan dan Kebudayaan Direktorat Jenderal Pendidikan Tinggi.

White, A. L.. 2010. Active Mathematics in Classrooms: Finding Out Why Children Make MistakesAnd Then Doing Something To help Them. Diambil dari http://www.curriculumsupport.education.nsw.gov.au/primary/mathematics/assets/pdf/sqone.p df.

Widadah, S. \& Afifah, D. S. N., \& Pos, J. J. K. (2013). Profil Metakognisi Siswa dalam Menyelesaikan Soal Sistem Persamaan Linear Dua Variabel Berdasarkan Gaya Kognitif. Jurnal Pendidikan Matematika STKIP PGRI Sidoarjo, 1(1), 13-24. 